\title{
Agronomic Performance of Spring Barley Cultivars under Different Eco-Environmental Conditions
}

\author{
Birzhan Usubaliev $^{1,3}$, Agnese Kolodinska Brantestam², Gulbubu Kurmanbekova ${ }^{3}$, \\ Kadyrbai Chekirov ${ }^{3}$, Nurzat Totubaeva ${ }^{4 *}$, Roland von Bothmer ${ }^{1}$ \\ ${ }^{11}$ Department of Plant Breeding, Swedish University of Agricultural Sciences, Alnarp, Sweden \\ ${ }^{2}$ Nordic Genetic Resource Center, Alnarp, Sweden \\ ${ }^{3}$ Department of Biology, Kyrgyz-Turkish Manas University, Bishkek, Kyrgyz Republic \\ ${ }^{4}$ Department of Environmental Engineering, Kyrgyz-Turkish Manas University, Bishkek, Kyrgyz Republic
}

Received: 22 October 2019

Accepted: 29 January 2020

\begin{abstract}
In this study, five agronomic traits of 29 barley accessions were evaluated in different agroenvironmental conditions. Accessions represented cultivars from Kyrgyzstan, Ukraine, and the Nordic and Baltic countries as well as landraces from northeastern and eastern Russia. The field experiments were carried out in two countries (Latvia and Kyrgyzstan) in order to select the suitable genotypes or cultivars as a source for Kyrgyz barley breeding programs. Among the accessions studied, we found material that can be used in Kyrgyz breeding as potential sources of earliness, spike length and TKW. Among the cultivars, 'Cecilia' from Sweden showed an attractive agronomic performance, and had constant behaviour under Kyrgyz climatic conditions during two years of trials. Other cultivars like 'Saana', 'Sencis' and 'Mette' can also be included in future breeding due to their earliness, plant height, spike length and number of kernels. There were cultivars that had the stabile response of number of agronomic characters in these two locations over both years of trials. For example, the cultivars 'Cecilia', Mette, 'Saana' were stable in HD, SL, and NGS in different climatic conditions. Also, among the landraces there were candidates who showed stable behaviour for SL and TKW.
\end{abstract}

Keywords: breeding, germplasm, cultivar, variety

\section{Introduction}

Barley (Hordeum vulgare L.) is an important cereal crop around the world and is of major importance to many countries [1-2]. In terms of global acreage and

*e-mail: totubaevanurzat@gmail.com nurzat.totubaeva@manas.edu.kg production, barley is the fourth major cereal crop after wheat, rice and corn globally [3], and is regarded as one of the most tolerant crops for drought and alkaline soils, and it has the highest water-use efficiency compared to other cereal crops, but it is less tolerant to acidic soils [4-7].

Cultivation conditions of barley genetic diversity are essential for adapting to future environmental changes, 
and are increasingly recognized as a crucial aspect of agricultural systems, especially considering the impacts of climate change [8-10].

The genetic variation between cultivars of barley and their related wild species easily gives way to use for the hybridization process in plant breeding. Barley has become a model plant experimental system for much scientific research around the world [11-18].

The cultivation conditions of barley are quite diverse, and the eco-geographic range from the highest arable mountain areas down to sea level and from high latitudes above the arctic circle to the tropics [19].

Knowledge about crop yield variability of crop cultivar is very useful regarding its selection and cultivation in a target region, as well as under specific cultivation regime [20]. Today, barley is grown on around $47.0 \mathrm{M} /$ ha across the globe [21]. It has great stability against climate fluctuations during the growing season, which reduces the risk for low yield in unfavorable years [22-23]. Major cereal yields are expected to decline significantly in coming years due to the effects of climate change temperature rise [24]. One advantage with barley is its ability to grow in harsh environments where most other crops would have difficulty to survive, for example in high-altitude areas (2.700-3.500 $\mathrm{m}$ a.s.1.) with a very short vegetation period [25-26].

Barley has thus a number of advantages as a cereal crop in mountainous areas of Central Asia, where the Kyrgyz Republic is one of the most mountainous agrarian countries. Agriculture is a significant economic sector of the country, and animal husbandry is a priority area, which has led to increasing barley production for feed since livestock every year - especially in the high mountain provinces of the country. For example, from 2005 to 2016 the number of sheep increased from 2.5 million up to 5.16 million heads [27].

Globally, population size will increase by 2050 and incomes will combine with dietary shifts to raise meat human consumption for each person to around $49 \mathrm{~kg}$ for the world (91 kg in high-income countries), and demand for total meat in Europe and Central Asia is projected to be 71 million tons [28]. Barley is considered the largest component of coarse grains used as animal feed [28], and globally, produced barley grain used for animal feed is about $35 \%$ of total grain produced.

Since barley is one of the most reliable crops for the majority of farmers in Kyrgyzstan, it is grown in all regions of the country, but dominates in the mountain provinces 'Issik-Kul' and 'Naryn' with prevailing severe winters and short summers. Spring barley is not only a universal crop but is also a substitute for winter crops. In years with massive loss of winter crops, farmers can expand the spring barley sowing. In most agricultural zones in Kyrgyzstan, barley is the most productive crop among spring cereals. The versatile use of barley grain for animal feed and the production of national drinks for human consumption further reinforces the importance of barley in grain production. An average of 238.5 metric tons was produced during the last five years. The area of barley cultivation during the last decade was around 243.000 hectares, but at present, due to unsuccessful agrarian reform, the total sown area of barley has been extremely reduced almost to half.

During the Soviet time there were altogether 574 major state farms, but after the independence of the country these larger kolkhozes and sovkhozes were split into many small private farms. Today, there are approximately 344,000 farms registered in Kyrgyzstan. The average yield of barley is very low and during the last five years (2012-2016) it was only about $1.9 \mathrm{t} / \mathrm{ha}$ [29]. The area of barley cultivation during the last decade was around 243,000 hectares, but at present, due to unsuccessful agrarian reform, the sown area of barley has been reduced by half [30].

The highly diverse climatic zones of Kyrgyzstan make it desirable to produce a variety of new cultivars of spring barley adapted to each zone with different growth conditions and duration of the growing season. For high mountain zones it is necessary to have early maturing cultivars, which can guarantee grain maturation during the short growth season. However, also for the central and south part of the country with longer growth seasons, early maturity cultivars are required. Here the cultivars must set grains before the start of the drought period. Another advantage of growing early maturing cultivars in these areas is that farmers can grow a second intermediate crop after barley, like maize for silage or vegetables. This allows for rational use of land resources for farmers.

High-input agricultural systems are becoming unsustainable due to a decrease in the availability of resources such as water, oil and phosphorus, which is further exacerbated by human population growth, which requires increasing levels of agricultural production [31]. Ecological intensification, where crop yield can increase through better use of resources, has been postulated as a possible solution [32-33].

Cultivars from other geographic regions of the world characterized by early maturity have successfully been used for cultivation as well as for barley-breeding purposes in Kyrgyzstan. For example, cultivars from the Baltic and other Soviet countries like 'Kombainieris' (Latvia), 'Doneskij 8', 'Odesskij 100' and Druzhva (Ukraine) have been on the variety list and they were also widely used in the breeding programs as donors for environmental adaptability. Well-studied germplasm gives better chances for the breeders to achieve their breeding goals. Hence, thoroughly characterized germplasm of different origins, possessing a complex of agronomic traits, are valuable sources that should be included as starting material for the breeding programs [34]. The current study forms part of a larger investigation of genetic resources for Kyrgyz barley breeding. The primary aim of this study was to analyze agronomic performance of spring barley cultivars in different agro-environmental conditions in order to seek valuable sources for the Kyrgyz' barley breeding program. 
Food supply is a major concern and takes place in a complex global scenario. On one side there is an increasing demand for food, i.e., the human population, projected to be 9 billion by 2050, and on the other side are factors that seriously threaten food production, i.e., climate change and the constant pressure of pests and pathogens, of which the global patterns of infection are also expected to vary due to this changing climate [35-36]. The organic farming sector is increasing in importance and requires varieties with stable yield and adapted to organic growing conditions [37].

\section{Materials and Methods}

\section{Plant Material}

The material consisted of 18 two-rowed and two six-rowed bred cultivars and nine landraces of spring barley, which were assessed in field trials in 2015 and 2016 (Table 1).

Table 1. Cultivar information of studied material in 2015 and 2016 (Kyrgyzstan and Latvia).

\begin{tabular}{|c|c|c|c|c|c|}
\hline Cultivar & $\begin{array}{c}\text { Genebank } \\
\text { ID }\end{array}$ & Origin & Pedigree & Released & $\begin{array}{l}\text { Row } \\
\text { type }\end{array}$ \\
\hline Local 1 & 18647 & Russia, Krasnoyarsk & Landrace & $1958 *$ & 6 \\
\hline Local 2 & 18059 & Russia, Krasnoyarsk & Landrace & $1951 *$ & 6 \\
\hline Gibrid 1N35-3E & 17021 & Russia, Omsk & Landrace & $1947 *$ & 6 \\
\hline Local 3 & 4963 & Russia, Omsk-local & Landrace & $1923 *$ & 6 \\
\hline Obyknovenniy 1 & 11689 & Russia, Altay & Landrace & $1929 *$ & 6 \\
\hline Obyknovenniy 2 & 11703 & Russia, Altay & Landrace & $1929 *$ & 6 \\
\hline Prostoy 1 & 11688 & Russia, Altay & Landrace & $1929 *$ & 6 \\
\hline Prostoy 2 & 16513 & Russia, Omsk & Landrace & $1939 *$ & 6 \\
\hline Local 4 & 4955 & Russia, Omsk-local & Landrace & $1923^{*}$ & 6 \\
\hline Jyva & - & Finland & Arve $\mathrm{x}$ Verner & 2000 & 6 \\
\hline Lavrance & NGB16727 & Norway & Vera//Arve/H82009-1-3 & 1999 & 6 \\
\hline Nutans 89 & - & Kyrgyzstan & Nutans 7554 x Kaskad & 1994 & 2 \\
\hline Taalay & - & Kyrgyzstan & F2 (Liniya25 x Harpoon) x F2 (Tyasmin x kaskad) & 1997 & 2 \\
\hline Bestam & - & Kyrgyzstan & $\begin{array}{c}\text { (Nutans 8884, naryn } 27 \text { x K-20431) x (Nutans } 4353 \\
\text { x Union) x Odesskyi 100) }\end{array}$ & 2003 & 2 \\
\hline Nutans 970 & - & Kyrgyzstan & Nutans 7554 x Kaskad & 1974 & 2 \\
\hline Odesskiy 100 & - & Ukrain & 77/74 x Hml 36462 & 1983 & 2 \\
\hline Kylym & - & Kyrgyzstan & F3 [F2(Dinat x Azyk) x naryn 27] & 2003 & 2 \\
\hline Naryn 27 & - & Kyrgyzstan & Nutans 45 x Nurans 4353 & 1972 & 2 \\
\hline Maksat & - & Kyrgyzstan & Nutans 66 x Temp & 2006 & 2 \\
\hline Vladlen & - & Kyrgyzstan & Nutans 3011 x (Nutans 1963 x Nutans 2578) & 2010 & 2 \\
\hline Vatan & - & Kyrgyzstan & Kurier x Jaspis & 2008 & 2 \\
\hline Saana & - & Finland & Kustaa x Hja 60758 & 1996 & 2 \\
\hline Mari & NGB1491 & Sweden & Mutation selected from X-ray treated Bonus & 1960 & 2 \\
\hline Sencis & LVA00015 & Latvia & Rupal/Ofir/Torkel & 1994 & 2 \\
\hline Mette & NGB9275 & Sweden & $(($ Ingrid $x$ Ansgar $` 2) x$ Varunda $\wedge 2) x$ & 1984 & 2 \\
\hline Pernilla & NGB1510 & Sweden & (Birgitta x Mari) x Gunilla & 1979 & 2 \\
\hline Kinnan & NGB9950 & Sweden & Etu x Ida & 1992 & 2 \\
\hline Cecilia & NGB13913 & Sweden & PL $1578-87 / 88045$ & 1998 & 2 \\
\hline Leelo & EST19 & Estonian & Ansgak/Sv2552//Elo & 1995 & 2 \\
\hline
\end{tabular}

* Year of enter in the catalog of N. I. Vavilov Research Institute of Plant Industry 
The field trials were carried out in two different agro-environmental climatic zones: one in Priekuli, Latvia $\left(57^{\circ} 19^{\prime} \mathrm{N}, 24^{\circ} 20^{\prime} \mathrm{E}\right.$, altitude $20 \mathrm{~m}$ a.s.l.) and a second in Issyk-Kul, Kyrgyzstan $\left(42^{\circ} 3^{\prime} 59.49^{\prime} \mathrm{N}\right.$, $76^{\circ} 53^{\prime} 9.59^{\prime} \mathrm{E}$, altitude $2000 \mathrm{~m}$ a.s.l).. The plant material was obtained from the Nordic Genetic Resource Center (www.nordgen.org), the N. I. Vavilov Institute of Plant Industry (http://vir.nw.ru) and from the Kyrgyz Research Institute of Farming (krif@mail.kg). The experiment layout was a randomized complete block design using two replicates and two years in both countries. Each entry was sown in two rows of onemeter length, keeping a distance of $15 \mathrm{~cm}$ between rows and $5 \mathrm{~cm}$ between plants. In Kyrgyzstan irrigation was applied during the vegetation period in both years, but in Latvia no irrigation was applied.

\section{Evaluation of Agronomic Traits}

Phenological observations and evaluations of five agronomic traits were done either directly in the field or in the laboratory after harvest. The five characters were: 1) heading day (HD), the number of days from sowing to the time when $50 \%$ of spikes had emerged from the flag leaf sheath; 2) plant height (PH), as measured from the soil surface to the top of the spike, excluding awns; 3) spike length (SL), measured from the base of spikes to the top of uppermost spikelet excluding awns; 4) number of grains per spike (NGS), total number of grains from a single spike; and 5) thousand kernel weight (TKW), was calculated by weighing two samples of 500 seeds.

\section{Analysis of Data}

The ANOVA (analysis of variance) for each agronomic trait was performed (Table 2). The relationships between cultivars were assessed using the multivariate PCA analysis for each location and year of the trial. Minitab 16.0 software was used for statistical analysis (Minitab Release 16 statistical software). For a comparison of agronomic traits between years, a paired t-test was used for each cultivar, whereas between countries for each cultivar was applied by the general linear model $(\mathrm{P} \leq 0.05)$.

\section{Results and Discussion}

Barley cultivation in Kyrgyzstan is practiced throughout the country and thus the growing area is covering a very wide range of agro-environmental zones. Since the agronomic performance of barley is essential for Kyrgyz farmers, breeders have to consider this while developing new cultivars. In breeding programs for specific target areas, studies of genotype $\mathrm{x}$ environment interactions can decidedly increase the probability to select for stable genotypes. A critical prerequisite for efficient spring barley breeding is hence to capture wide genetic variation of desirable agronomic traits in the working collection of the breeding program [37-38].

The PCA analysis was made based on all five characters from the field trials according to location (Kyrgyzstan and Latvia) and cultivation year (2015 and 2016). For all cultivars, the first component visualized 37.5 to 42.0 per cent of the total variation, whereas the second component explained 24.9 to 31.9 per cent of the total variation, respectively (Fig. 1a).

The first component distinguished the two- and sixrowed types. In our study with the separation based on row types, two- and six-rowed cultivars were affected mainly by the number of grains per spike (NGS) and heading days (HD). The second component was mainly affected by (SL), (HD) and (TKW). However, the cultivars' responses to environmental conditions in different locations were different, and it can be seen in PCA analysis that the cultivars grouped differently in

Table 2. ANOVA analysis for each agronomic traits based on data from two different years (2015-2016) at two locations (Kyrgyzstan and Latvia).

\begin{tabular}{|c|c|c|c|c|c|c|c|}
\hline \multirow{2}{*}{ Source } & DF & HD & PH & SL & \multicolumn{2}{|c|}{ NGS } & TKW \\
\cline { 2 - 7 } & \multicolumn{7}{|c|}{ Mean squares } \\
\hline Cultivar & 28 & $55,57^{*}$ & $635,70^{*}$ & $5,35^{*}$ & $2351,83^{*}$ & $136,28^{*}$ \\
\hline Location & 1 & $2286,71^{*}$ & $85092,5^{*}$ & $87,3628^{*}$ & $6736,39^{*}$ & $2508,75^{*}$ \\
\hline Year (Location) & 2 & $118,192^{*}$ & $3874,9^{*}$ & $24,1229^{*}$ & $31,29^{\text {ns }}$ & $3701,93^{*}$ \\
\hline Repication (Location) & 4 & $3,68^{\text {ns }}$ & $17,90^{\text {ns }}$ & $0,86^{\text {ns }}$ & $30,83^{\text {ns }}$ & $4,33^{\text {ns }}$ \\
\hline Cultivar*Location & 28 & $17,729^{*}$ & $89 *$ & $1,0193^{*}$ & $251,02^{*}$ & $81,03^{*}$ \\
\hline Cultivar*Year (Location) & 56 & $21,115^{*}$ & $110,5^{*}$ & $0,986^{*}$ & $39,79^{*}$ & $47,83^{*}$ \\
\hline Error & 112 & 2,04 & 8,40 & 0,34 & 13,98 & 3,46 \\
\hline Total & 231 & & & & & \\
\hline
\end{tabular}

* Significant at 0.001 level, ns-not significant, DF-degree of freedom, HD- heading day, PH-plant height, SL-spike length, NGSnumber of grains in spike, TKW-thousand kernels weight. 
2015 All cultıvars
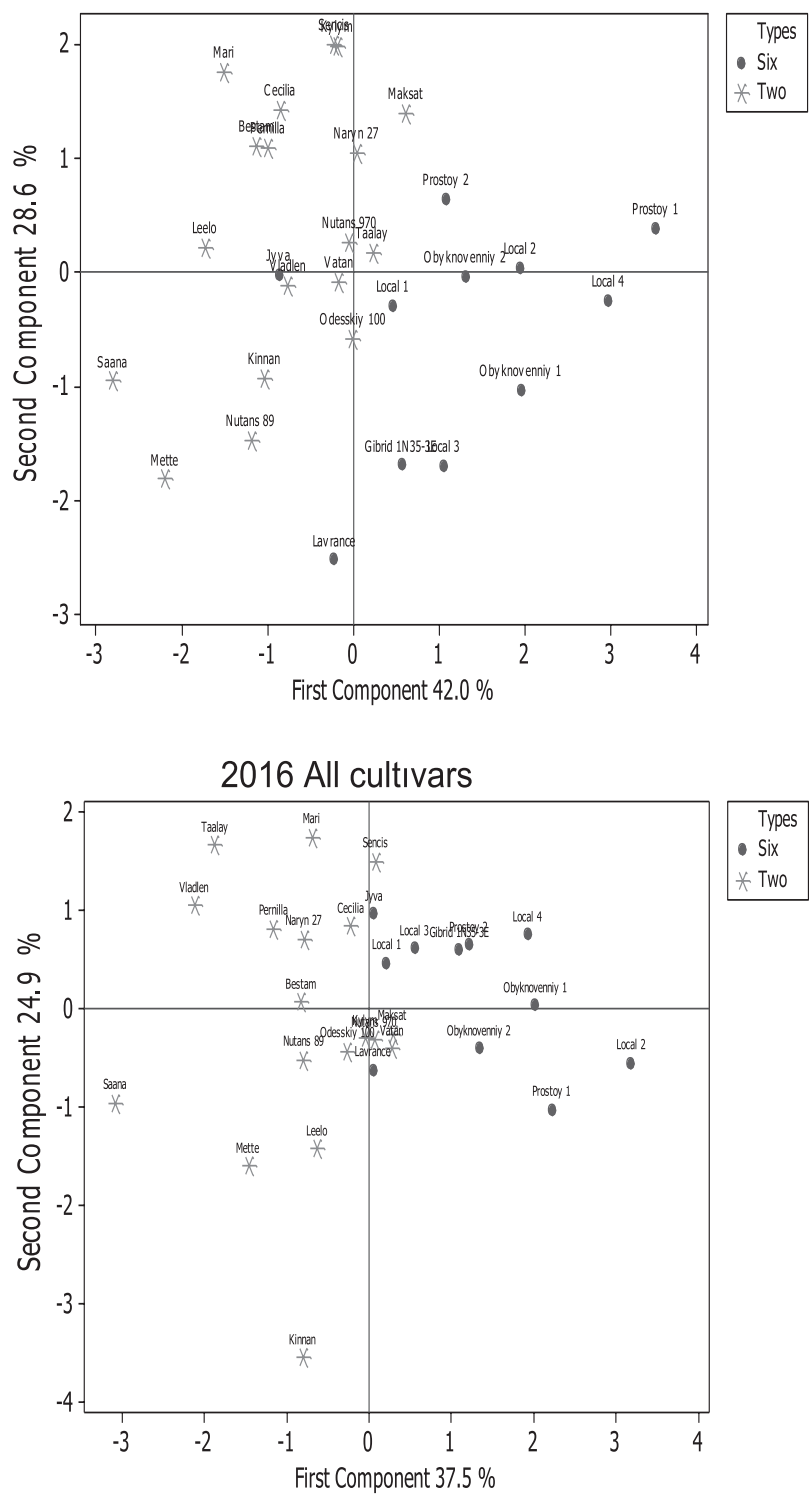

2015 All cultivars
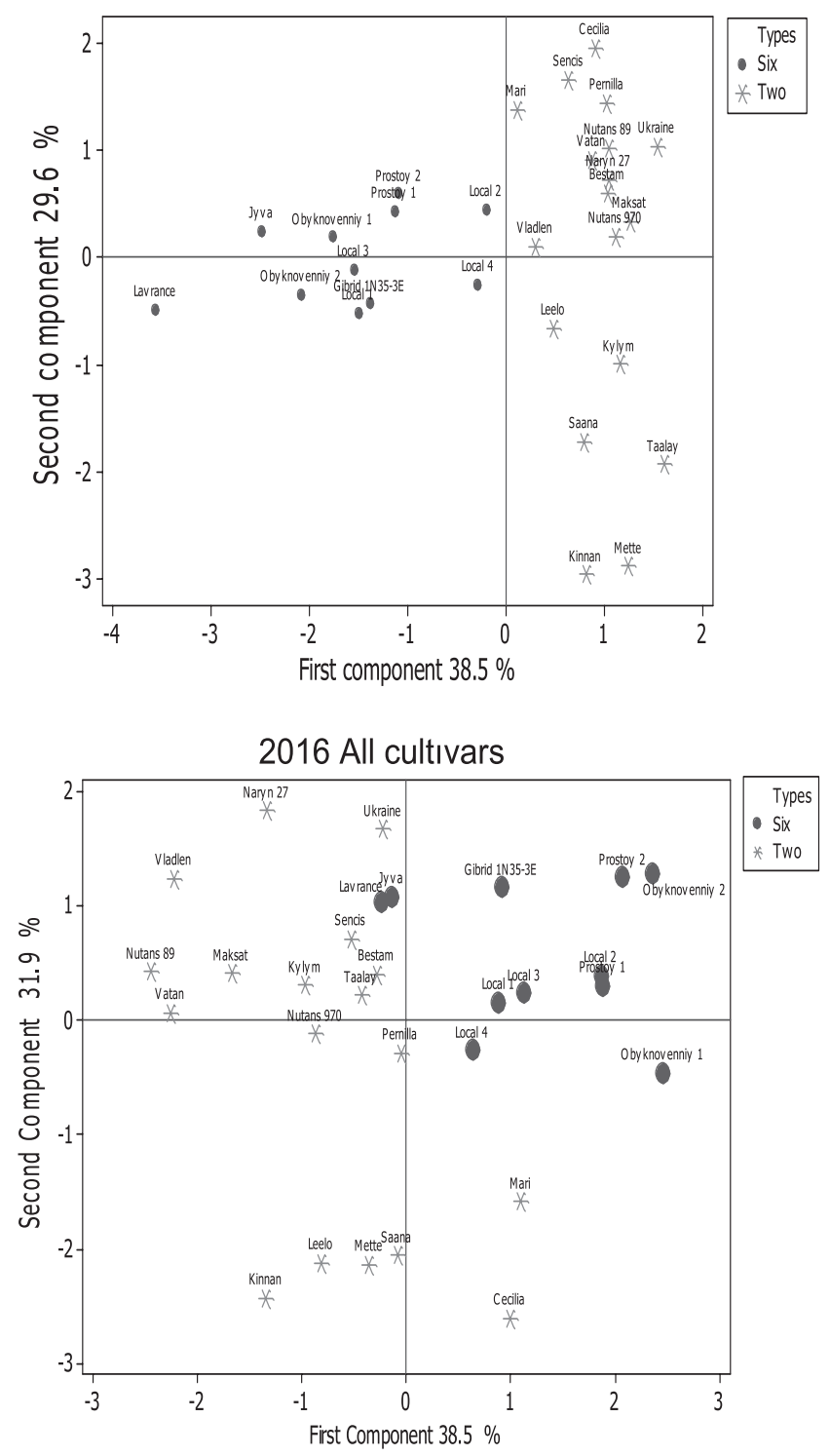

Fig. 1a). PCA analysis based on agronomic traits of all cultivars, Kyrgyzstan and Latvia (2015-2016).

each country and each year. When the PCA analysis was done for only two-rowed cultivars, the first component explained 41.6 to 61.8 per cent of the variation, whereas the second component accounted for 16.7 to 39.8 per cent of the variation (Fig. 1b). Based on trial data, the first component was mainly affected by the number of grains per spike (NGS) in Kyrgyzstan and plant height $(\mathrm{PH})$, whereas the second component was affected by heading day (HD). In Latvia, the first component was mainly affected by thousand kernels weight (TKW), and the second component was affected by HD. There was no clear group of accession based on PCA analysis (data not shown). Similarly, the PCA was done for six-rowed cultivars and the first component accounted for 41.5 to $50.1 \%$, whereas the second component explained 23.1 to 26.1 per cent. In the PCA based on data from trials in Kyrgyzstan for six-rowed cultivars, the first component was affected by PH, TKW and HD, while the second component was mainly affected by HD and NGS. The PCA for six-rowed cultivars based on data from the Latvian trials saw the first component mainly affected by HD, PH and NGS, whereas the second component was affected by TKW, PH and NGS. In Latvian trials there was apparent separation of the cultivars 'Jyva' and 'Lacrance' from other six-rowed accessions shown by the first component of PCA, whereas in trials from Kyrgyzstan this separation was less pronounced.

The ANOVA analysis for each of the five agronomic parameters showed that there were significant differences between the cultivars (Table 2). This indicates that a genetic diversity resides among the analysed cultivars. The effect of the location and year was also significant for all traits. A significant effect of the environment $\mathrm{x}$ cultivar interaction was detected for all traits analyzed, as well as for interaction of cultivar $\mathrm{x}$ year (location). In this study there was no 
Kyrgyzstan 2015 Six rowed cultivars

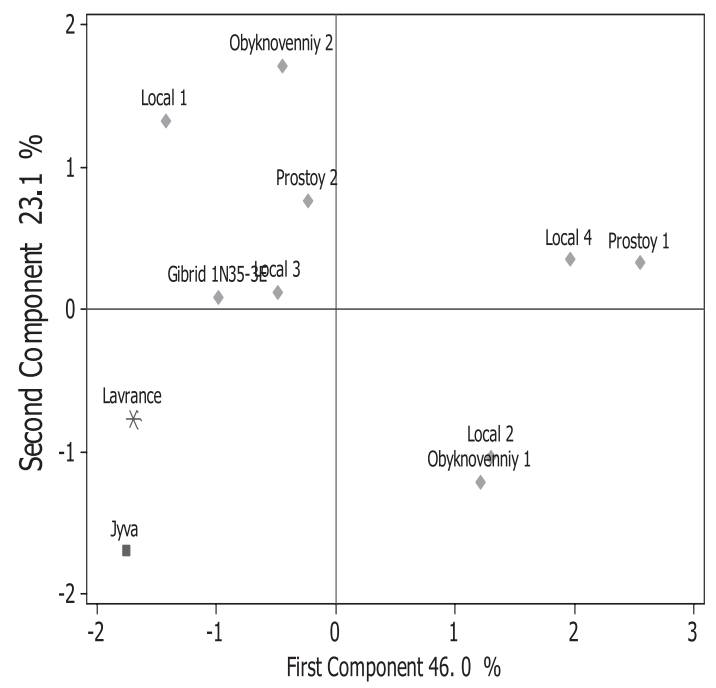

Kyrgyzstan 2016 Six rowed cultivars

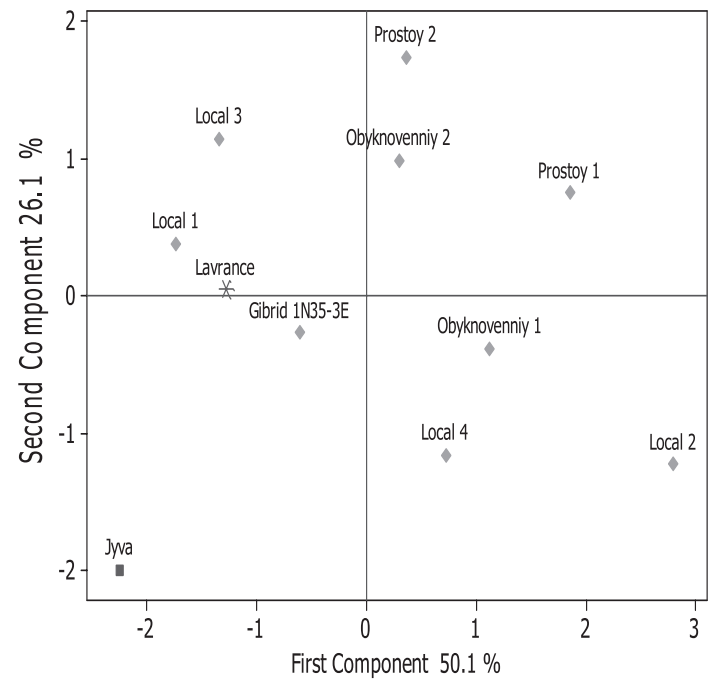

Latvia 2015 Six rowed cultivars
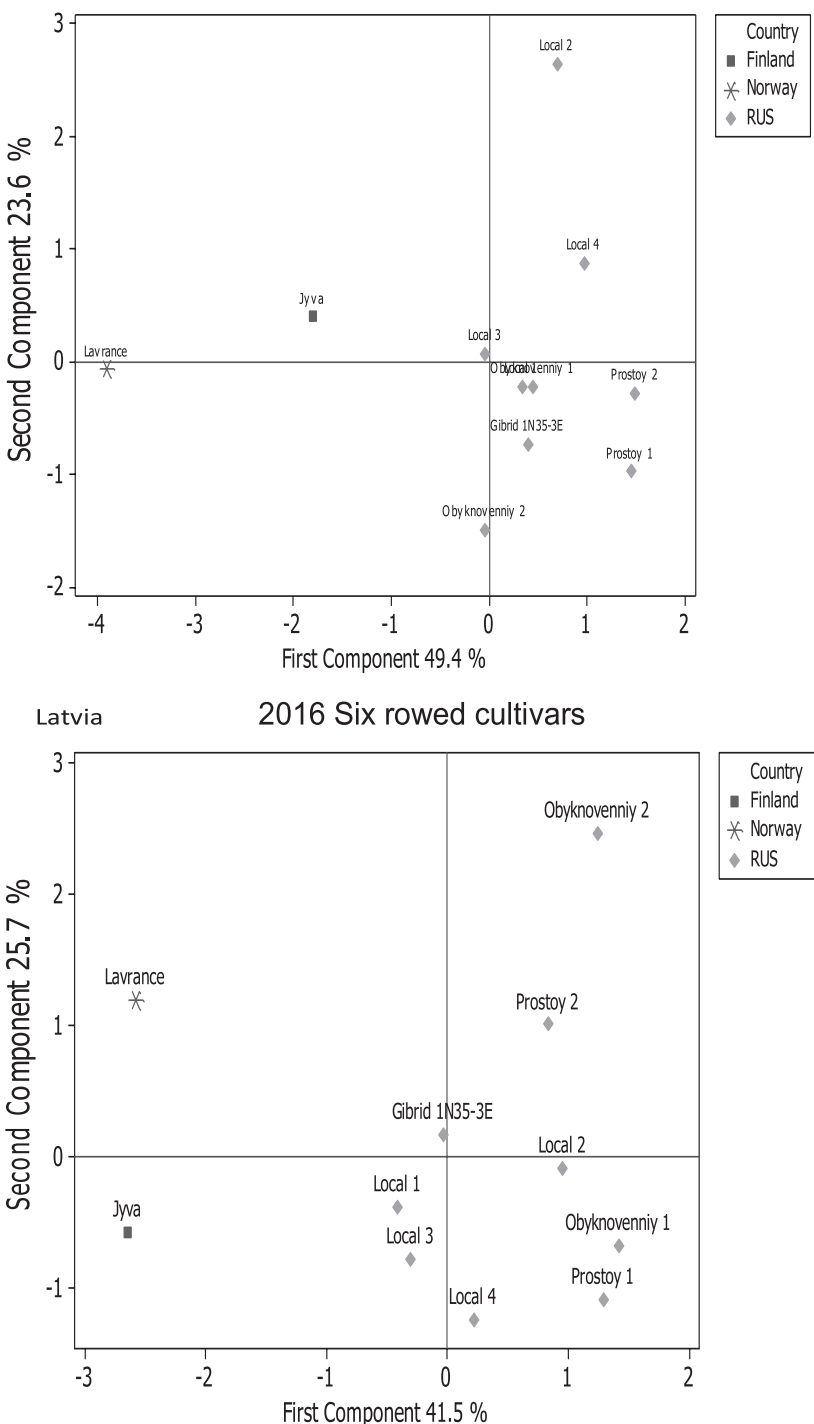

Fig. 1b). PCA analysis based on agronomic traits, six-rowed cultivars, Kyrgyzstan and Latvia (2015-2016).

significant difference between different years within the same trial sites for the NGS trait (Table 2). Bleidere et al. [38] and Dofing et al. [39] studying advanced bred cultivars of spring barley reported similar results in their studies showing significant interactions for environment $\mathrm{x}$ cultivar in different climatic conditions. One of the reasons for the environmental effect between Kyrgyzstan and Latvia is that there are differences in day lengths. In Latvia the average day from May to September is 15.7 hours, whereas in Kyrgyzstan the average length is only 13.7 hours (Table 3). Thus, the numbers of days to heading (HD) in the Latvian field-trial were significantly lower compared to the corresponding field trial in Kyrgyzstan. The number of days heading for the cultivars in Kyrgyzstan in 2015 varied from 58 to 67 days with an average of 63 days, whereas in 2016 the HD values ranged from 58 to 72 days with an average of 64 days. The heading day values of most cultivars were fairly constant over the two years. In Kyrgyzstan there was not a significant difference in (HD) for most bred cultivars between 2015 and 2016, but there is a significant difference in response of Russian six-rowed landraces between the two trial years (Fig. 2). This may be due to the fact that bred cultivars have less variation in response to yearto-year variation than landraces. In the Latvian trials there were more differences between the heading day values as compared to the Kyrgyz trial, where only nine accessions did not show significant differences over the two trial years in this trait.

The cultivar 'Mette' showed not only no significant differences in the $\mathrm{DH}$ response between years, but also no significant difference $(\mathrm{P} \leq 0.08)$ between countries. Among the two-rowed barleys the cultivars 'Vladlen', Taalay and 'Naryn 27' were the earliest maturing cultivars in both years (58 and 61 days, respectively), whereas among the six-rowed cultivars 'Gibrid 1N35-3E' and 'Local 3' were the earliest, but 
Table 3. Meteorological data for Kyrgyzstan and Latvia 2015-2016 (May-September).

\begin{tabular}{|c|c|c|c|c|}
\hline KG 2015 & $\begin{array}{l}\text { Average temperature }{ }^{\circ} \mathrm{C} \\
\text { (min-max) }\end{array}$ & Average moisture $\%$ & Total rainfall, $\mathrm{mm}$ & Average day length (Hours) \\
\hline May & $12(10-17)$ & 58 & 36 & 14 \\
\hline June & $17(13-23)$ & 59 & 40 & 15 \\
\hline July & $19(14-25)$ & 59 & 68 & 15 \\
\hline August & $19(14-23)$ & 61 & 103 & 13 \\
\hline September & $14(10-19)$ & 67 & 100 & 12 \\
\hline \multicolumn{5}{|c|}{ KG 2016} \\
\hline May & $14(9-19)$ & 71 & 71 & 14 \\
\hline June & $17(12-23)$ & 65 & 55 & 15 \\
\hline July & $19(14-25)$ & 59 & 16 & 15 \\
\hline August & $19(14-24)$ & 56 & 26 & 13 \\
\hline September & $16(11-22)$ & 62 & 12 & 12 \\
\hline \multicolumn{5}{|c|}{ Latvia 2015} \\
\hline May & $13(9-18)$ & 75 & 91 & 16 \\
\hline June & $15(11-19)$ & 77 & 96 & 17 \\
\hline July & $22(17-27)$ & 73 & 76 & 17 \\
\hline August & $19(15-23)$ & 82 & 113 & 17 \\
\hline September & $11(8-15)$ & 85 & 92 & 12 \\
\hline \multicolumn{5}{|c|}{ Latvia 2016} \\
\hline May & $12(7-17)$ & 69 & 67 & 16 \\
\hline June & $18(13-23)$ & 70 & 46 & 17 \\
\hline July & $20(16-25)$ & 75 & 77 & 17 \\
\hline August & $17(13-22)$ & 78 & 115 & 17 \\
\hline September & $13(10-17)$ & 84 & 51 & 12 \\
\hline
\end{tabular}

not in each country. There were differences in rainfall (Table 3) in the beginning of the vegetation period between two years, which could affect the HD. It should be mentioned that in Kyrgyzstan irrigation was applied twice during the vegetation period, which could have reduced the effect of the differences between years (Fig. 2). In Latvian trials no irrigation was carried out and generally the lower precipitation in spring of 2016 resulted in decreased values of HD for the majority of accessions. Some exceptions could be detected, as cultivars 'Saana', 'Kinnan', 'Cecillia', and 'Leelo' had significantly longer periods before heading in 2016 as compared to 2015. Studying genetic diversity of Nordic and Baltic barley cultivars [40] showed that there was a difference between two- and six-rowed barleys in heading days, and that six-rowed barleys were earlier maturing than two-rowed barley. However, in our study also the six-rowed cultivars were separated from the two-rowed cultivars by the characters HD and NGS. The number of days in Latvia 2015 ranged from 52 to 63 , with an average of 58 days in 2015 and in 2016 the HD values varied between 44 and 67, with an average of 56 days. Most Kyrgyz cultivars were earlier in heading when cultivated in Latvia but they showed somewhat different responses in the two different years. Several reports have previously mentioned that there are noticeable genotype $\mathrm{x}$ environmental interactions for heading values of barley [41]. The interaction between genotype and environment is one of the major problems facing barley breeding programs aimed at achieving the desired breeding targets in new cultivars to be used over larger cultivation areas in different environments [42]. The value heading day is such a determinative trait of adaptation for cultivars to particular environment areas, which defines the crop performance in different agro-environmental conditions [43]. Among the overall studied material, most of the two-rowed cultivars revealed a more stable response to year-to-year variation within the trial site For example, foreign cultivars from Nordic and Baltic countries 'Mette' $(\mathrm{P}=0.28, \mathrm{P}=0.10)$ and 'Pernilla' $(\mathrm{P}=0.68, \mathrm{P}=0.420)$, 'Mari'( $\mathrm{P}=0.18$, $\mathrm{P}=0.26)$ from Sweden and 'Sencis' $(\mathrm{P}=0.80, \mathrm{P}=0.14)$ 
Table 4. P-values in comparison of agronomic traits between Kyrgyzstan and Latvia.

\begin{tabular}{|c|c|c|c|c|c|}
\hline Cultivars & Heading day & Plant height & Spike length & Number of grains in spike & TKW \\
\hline Local 1 & 0,00 & 0,00 & 0,12 & 0,00 & 0,05 \\
\hline Local 2 & 0,03 & 0,00 & 0,00 & 0,00 & 0,96 \\
\hline Gibrid 1N35-3E & 0,01 & 0,00 & 0,46 & 0,00 & 0,29 \\
\hline Local 3 & 0,04 & 0,01 & 0,30 & 0,00 & 0,00 \\
\hline Obyknovenniy 1 & 0,03 & 0,01 & 0,01 & 0,00 & 0,00 \\
\hline Obyknovenniy 2 & 0,05 & 0,00 & 0,24 & 0,13 & 0,36 \\
\hline Prostoy 1 & 0,08 & 0,00 & 0,12 & 0,00 & 0,23 \\
\hline Prostoy 2 & 0,02 & 0,00 & 0,02 & 0,25 & 0,19 \\
\hline Local 4 & 0,24 & 0,00 & 0,01 & 0,00 & 0,11 \\
\hline Jyva & 0,00 & 0,00 & 0,08 & 0,02 & 0,06 \\
\hline Lavrance & 0,00 & 0,00 & 0,02 & 0,33 & 0,65 \\
\hline Nutans 89 & 0,01 & 0,04 & 0,17 & 0,05 & 0,27 \\
\hline Taalay & 0,84 & 0,00 & 0,02 & 0,05 & 0,05 \\
\hline Bestam & 0,00 & 0,00 & 0,61 & 0,01 & 0,25 \\
\hline Nutans 970 & 0,02 & 0,00 & 0,01 & 0,02 & 0,93 \\
\hline Odesskiy 100 & 0,00 & 0,00 & 0,23 & 0,87 & 0,02 \\
\hline Kylym & 0,00 & 0,00 & 0,00 & 0,22 & 0,89 \\
\hline Naryn 27 & 0,01 & 0,00 & 0,02 & 0,01 & 0,69 \\
\hline Maksat & 0,04 & 0,00 & 0,11 & 0,13 & 0,72 \\
\hline Vladlen & 0,01 & 0,00 & 0,12 & 0,09 & 0,12 \\
\hline Vatan & 0,02 & 0,01 & 0,06 & 0,04 & 0,42 \\
\hline Saana & 0,39 & 0,04 & 0,00 & 0,39 & 0,00 \\
\hline Mari & 0,02 & 0,00 & 0,09 & 0,83 & 0,00 \\
\hline Sencis & 0,00 & 0,00 & 0,02 & 0,03 & 0,20 \\
\hline Mette & 0,28 & 0,00 & 0,04 & 0,03 & 0,00 \\
\hline Pernilla & 0,01 & 0,00 & 0,07 & 0,42 & 0,02 \\
\hline Kinnan & 0,01 & 0,00 & 0,02 & 0,00 & 0,38 \\
\hline Cecilia & 0,08 & 0,01 & 0,06 & 0,06 & 0,00 \\
\hline Leelo & 0,00 & 0,00 & 0,02 & 0,01 & 0,01 \\
\hline
\end{tabular}

from Latvia one Kyrgyz cultivar 'Nutans 970' $(\mathrm{P}=0.06, \mathrm{P}=0.12)$ and one Ukrainian cultivar 'Odesskiy 100 ') $(\mathrm{P}=0.77, \mathrm{P}=0.09)$ are especially promising by showing similar heading day performance within both countries, and there was no significant difference between them over the two years. However, there were few cultivars ('Mette', 'Saana', 'Cecilia', 'Taalay') and landraces ('local 4', 'Prostoy 1' and 'Obyknovenniy 1') that showed more stable response of the character in heading days, also when compared between trial sites and years (Table 4). Another important trait is plant height, which in our study is demonstrated by variation over the two years in both countries. Plant height is one of the traits that can be influenced by the environment, especially by drought [44], which is an abiotic stress that affects plants at various levels and stages of their life. This abiotic stress not only affects plant-water relations through the reduction of water content, turgor, and total water, but it also affects stomatal closure, limits gas exchange, reduces transpiration, and disturbs photosynthesis [45-46]. Differences between cultivars regarding plant height mainly depend on genetic background of the cultivars and it is a highly heritable trait [47-48]. A tall plant is an undesirable characteristic since grain yield can be reduced by lodging [49-50]. In this study, the plant height of cultivars varied between 
a)

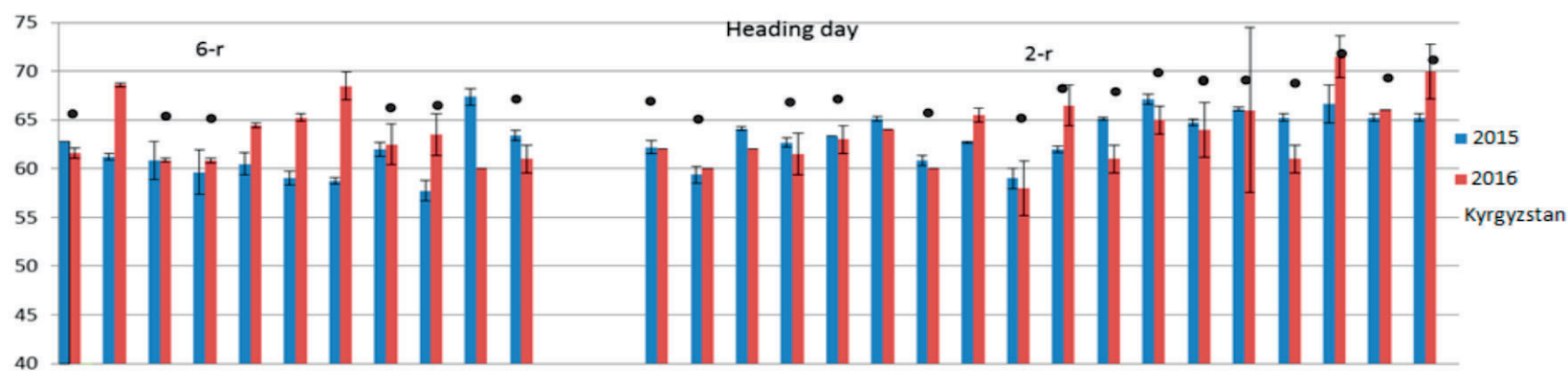

b)

75

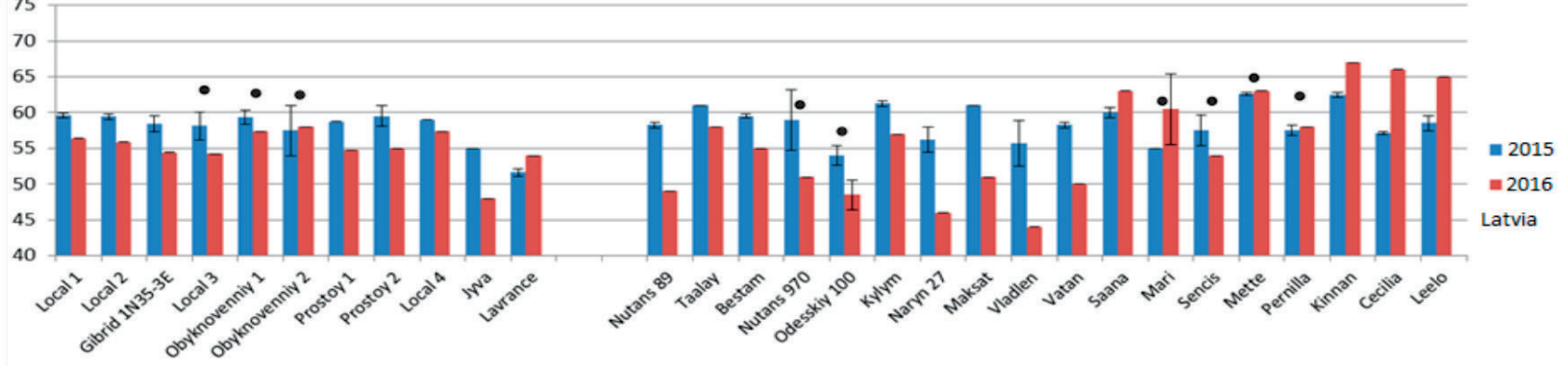

a) 130

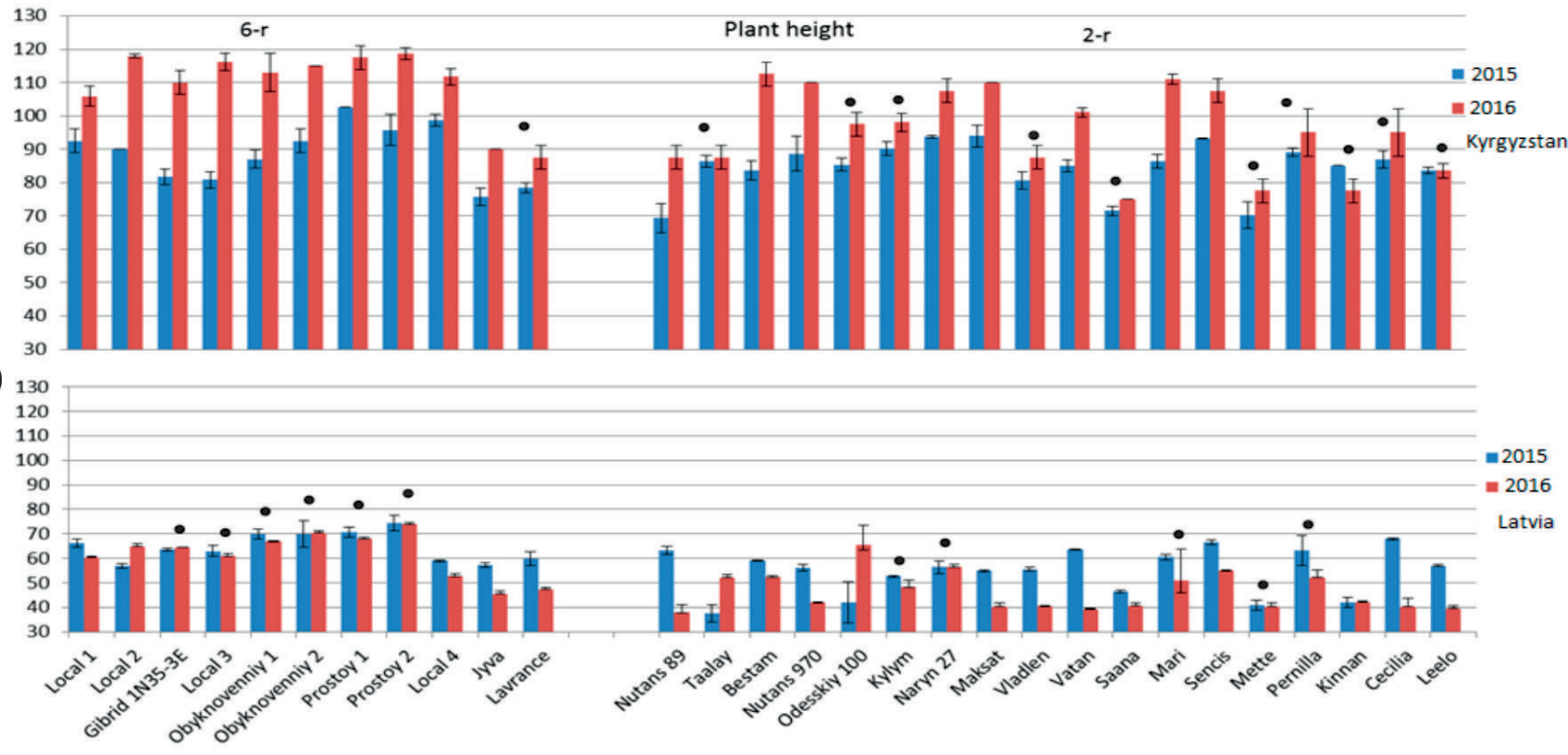

a)
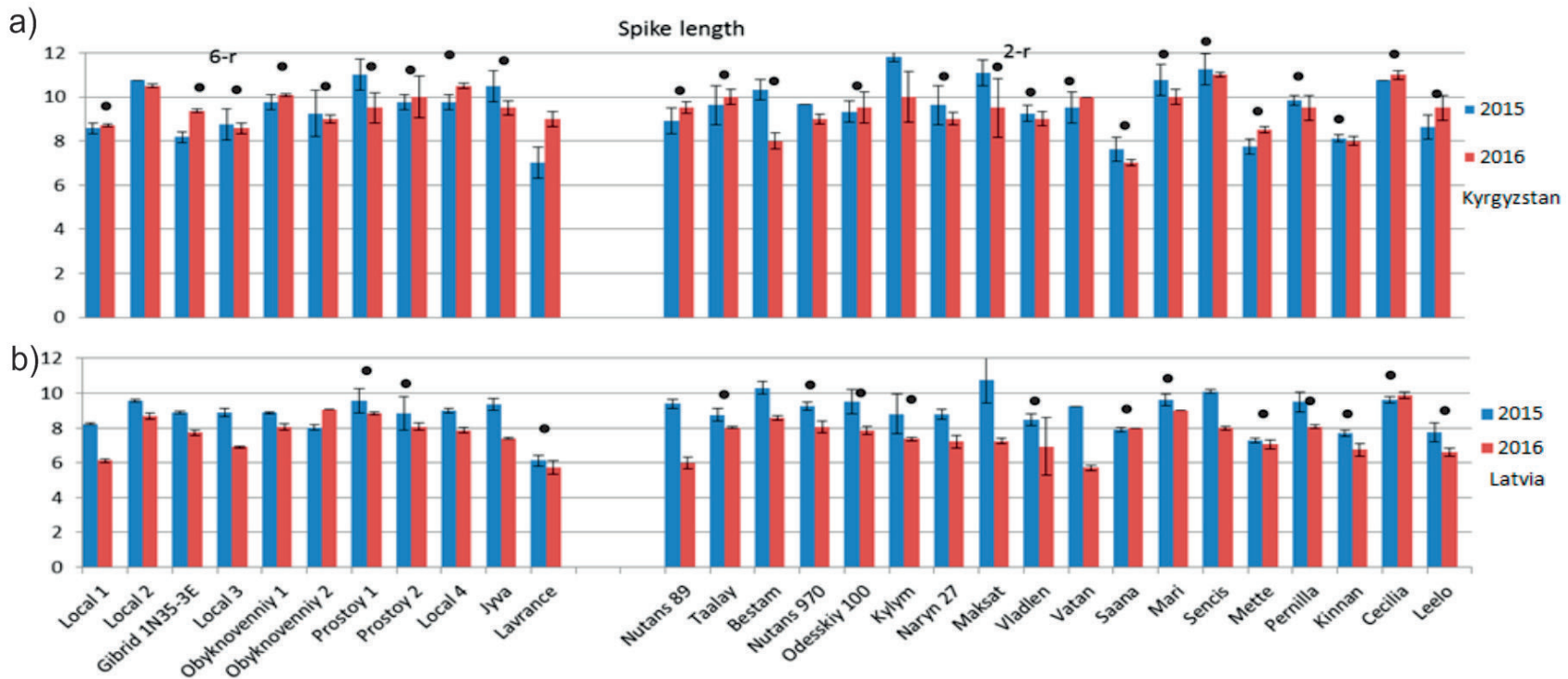

Fig. 2. Agronomic traits of 29 spring barley grown in Kyrgyzstan a) and Latvia b) $2015-2016 ; \boldsymbol{\bullet}=$ not significant at $\mathrm{P} \leq 0.05$. 
a)

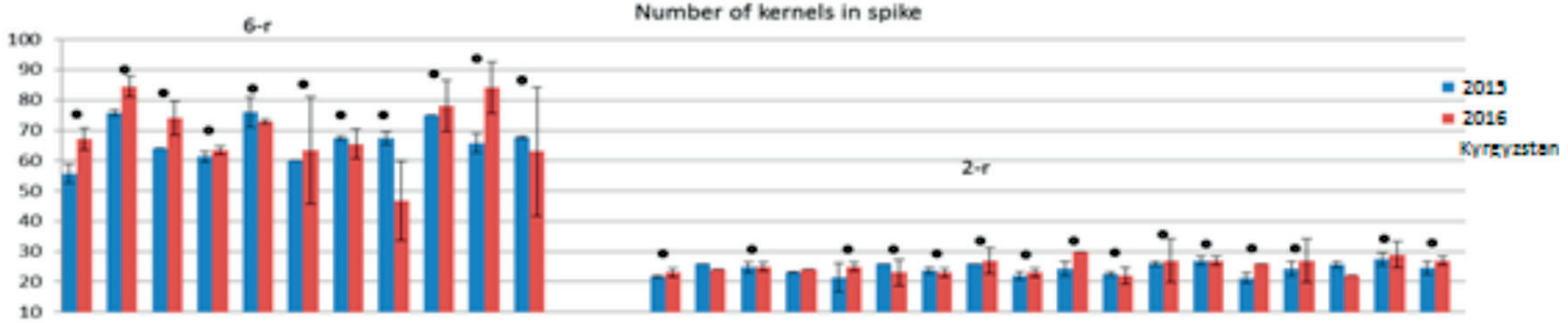

b) 90

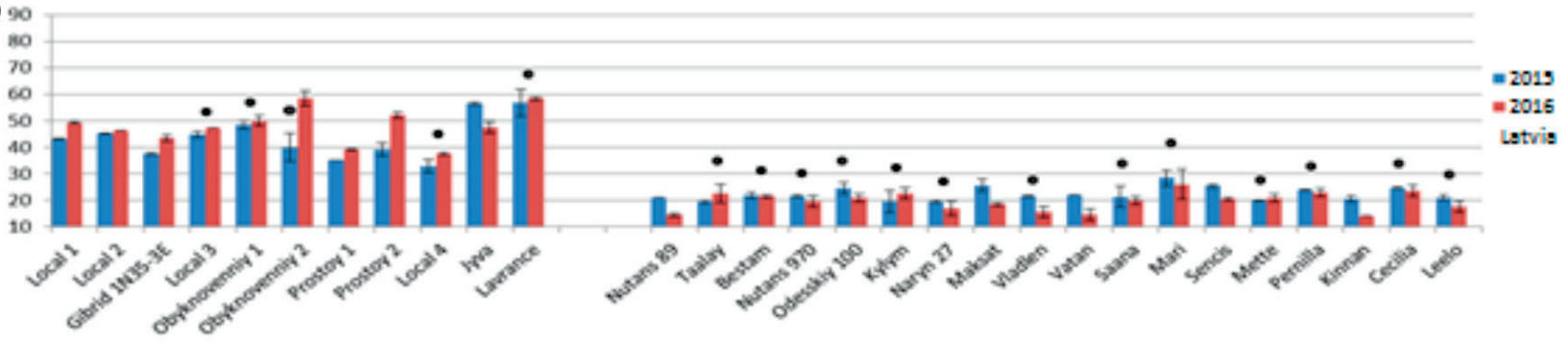

a)

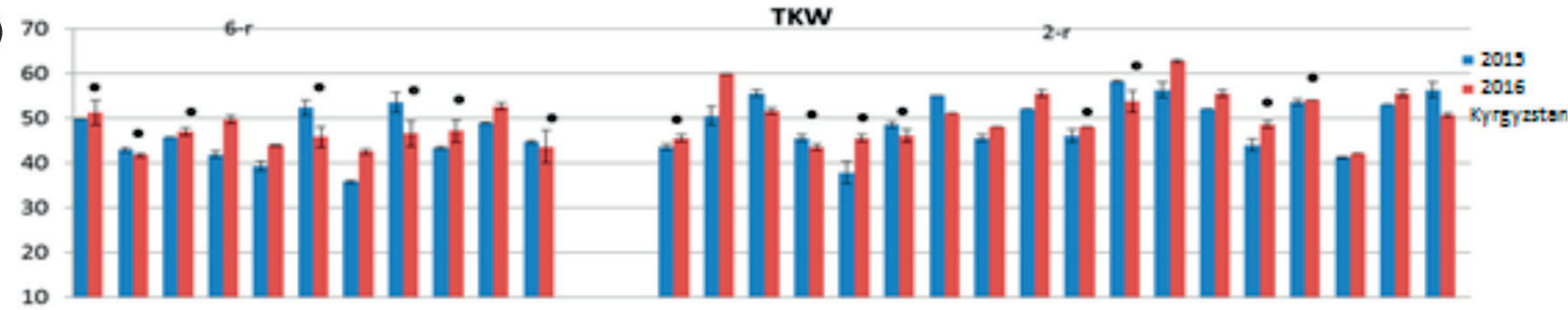

b)

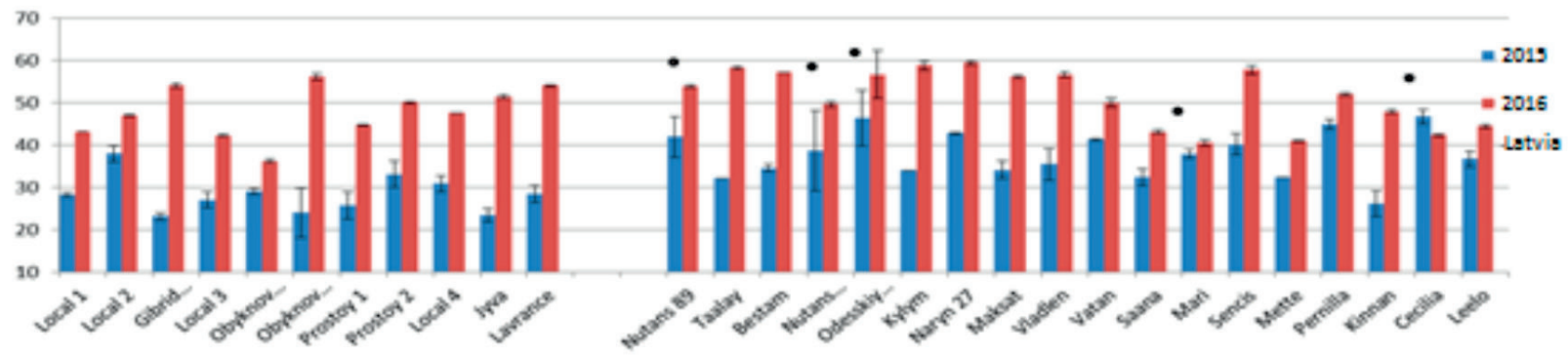

Fig. 2. Continued.

years of the trials and ranged from 32 up to $119 \mathrm{~cm}$ (Kyrgyzstan and Latvia). In general, the PH values were higher in 2016 than in 2015 in Kyrgyzstan. This may be an effect of low precipitation in $2010(36 \mathrm{~mm})$ during the beginning of the vegetation period (May-June), whereas the rainfall was higher in 2011 during these months (Table 3). Hence, in the case of low moisture content in the soil it is necessary to provide irrigation in order to supply optimum growth conditions. In most provinces it is possible to provide irrigation during the vegetation period, especially during the early stages of plant development. However, in areas where the irrigation water is limited, barley is still cultivated despite rain-fed, unfavorable field conditions. In Kyrgyzstan the plant heights of the cultivars ranged from 69 to $103 \mathrm{~cm}$ (average $86 \mathrm{~cm}$ ) in 2015, whereas the $\mathrm{PH}$ value ranged from 75 to $119 \mathrm{~cm}$ (average $101 \mathrm{~cm}$ ) in 2016. Generally, the plants were taller in 2016 as compared to the 2015 with only a few exceptions among the two-rowed cultivars (Fig. 2a), Appendix 1). The corresponding $\mathrm{PH}$ values from the field trials in Latvia ranged from 38 to $74 \mathrm{~cm}$ (average $58 \mathrm{~cm}$ ) in 2015 and they had the same range (average $52 \mathrm{~cm}$ ) in 2016. The six-rowed Russian landraces were comparatively taller than the Nordic cultivars in both years (Fig. 2b). However, a paired t/test showed that there were a few landraces or cultivars, which showed a sustained performance between years in each country (Fig. 2a-b) but there was a significant difference $(\mathrm{P}<0.05)$ between the two countries in plant height. The plant height $(\mathrm{PH})$ character of the cultivars 'Kylym', 'Saana', 'Mette' and 'Kinnan' had rather constant behaviour during the two years at each trial site. In Latvia there were no differences in $\mathrm{PH}$ between the two years for cultivar 'Naryn 27' $(\mathrm{P}=0.94)$ and six of the Russian landrace accessions. Kyrgyz cultivars 'Kylym' and 'Naryn 27' are recommended for rain-fed cultivation, and also the two Swedish cultivars 'Kinan' and 'Mette' differed 


\begin{tabular}{|c|c|c|c|c|c|c|c|c|c|c|c|c|c|c|c|c|c|c|c|c|}
\hline & & & & & kyrgyz & & & & & & & & & & Latvla & & & & & \\
\hline & & & 2015 & & & & & 2016 & & & & & 2015 & & & & & 2016 & & \\
\hline Cultivars & 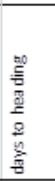 & 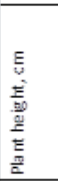 & 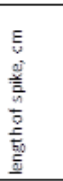 & 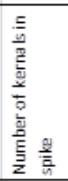 & 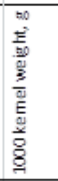 & 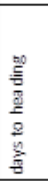 & 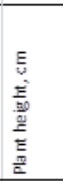 & 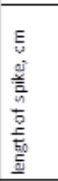 & 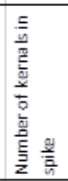 & 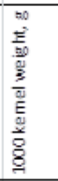 & 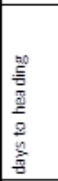 & 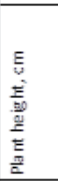 & 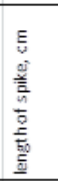 & 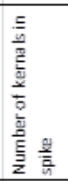 & 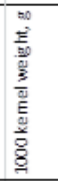 & 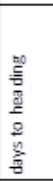 & 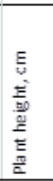 & 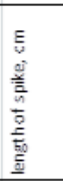 & 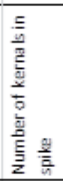 & 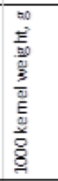 \\
\hline Local 1 & 63 & 93 & 9 & 56 & 50 & 62 & 106 & 9 & 67 & 51 & 60 & 66 & 8 & 43 & 28 & 56 & 60 & 6 & 49 & 43 \\
\hline Local 2 & 61 & 90 & 11 & 76 & 43 & 69 & 118 & 11 & 85 & 42 & 59 & 57 & 10 & 45 & 38 & 56 & 65 & 9 & 46 & 47 \\
\hline Glbrid 1N35-3E & 61 & 82 & 8 & 64 & 46 & 61 & 110 & 9 & 74 & 47 & 58 & 63 & 9 & 38 & 23 & 54 & 64 & 8 & 44 & 54 \\
\hline Local 3 & 60 & 81 & 9 & 61 & 42 & 61 & 116 & 9 & 63 & 50 & 58 & 63 & 9 & 45 & 27 & 54 & 61 & 7 & 47 & 42 \\
\hline Obyknovennly 1 & 61 & 87 & 10 & 76 & 39 & 65 & 113 & 10 & 73 & 44 & 59 & 70 & 9 & 49 & 29 & 57 & 67 & 8 & 50 & 36 \\
\hline Obyknovennly 2 & 59 & 93 & 9 & 60 & 52 & 65 & 115 & 9 & 64 & 46 & 58 & 70 & 8 & 40 & 24 & 58 & 70 & 9 & 59 & 56 \\
\hline Prostoy 1 & 59 & 103 & 11 & 68 & 36 & 69 & 118 & 10 & 66 & 42 & 59 & 71 & 10 & 35 & 26 & 55 & 68 & 9 & 39 & 45 \\
\hline Prostoy 2 & 62 & 95 & 10 & 68 & 54 & 63 & 119 & 10 & 47 & 45 & 60 & 74 & 9 & 39 & 33 & 55 & 74 & 8 & 52 & 50 \\
\hline Local 4 & 58 & 99 & 10 & 75 & 43 & 64 & 112 & 11 & 78 & 47 & 59 & 59 & 9 & 33 & 31 & 57 & 53 & 8 & 38 & 47 \\
\hline Jyva & 67 & 76 & 11 & 66 & 49 & 60 & 90 & 10 & 84 & 53 & 55 & 57 & 9 & 57 & 23 & 48 & 45 & 7 & 48 & 51 \\
\hline Lavrance & 63 & 78 & 7 & 68 & 45 & 61 & 88 & 9 & 63 & 44 & 52 & 60 & 6 & 57 & 28 & 54 & 47 & 6 & 59 & 54 \\
\hline Nutans 89 & 62 & 69 & 9 & 22 & 44 & 62 & 88 & 10 & 23 & 45 & 58 & 63 & 9 & 21 & 42 & 49 & 38 & 6 & 15 & 54 \\
\hline Taalay & 59 & 86 & 10 & 25 & 51 & 60 & 88 & 10 & 24 & 60 & 61 & 38 & 9 & 20 & 32 & 58 & 52 & 8 & 23 & 58 \\
\hline Bestam & 64 & 84 & 10 & 25 & 56 & 62 & 113 & 8 & 25 & 52 & 60 & 59 & 10 & 22 & 35 & 55 & 52 & 9 & 22 & 57 \\
\hline Nutans 970 & 63 & 89 & 10 & 23 & 45 & 62 & 110 & 9 & 24 & 44 & 59 & 56 & 9 & 21 & 39 & 51 & 42 & 8 & 20 & 50 \\
\hline Odesskly 100 & 63 & 85 & 9 & 21 & 38 & 63 & 98 & 10 & 25 & 46 & 54 & 42 & 10 & 25 & 46 & 49 & 66 & 8 & 21 & 57 \\
\hline Kylym & 65 & 90 & 12 & 26 & 49 & 64 & 98 & 10 & 23 & 45 & 61 & 53 & 9 & 20 & 34 & 57 & 48 & 7 & 23 & 59 \\
\hline Naryn 27 & 61 & 94 & 10 & 24 & 55 & 60 & 108 & 9 & 23 & 51 & 56 & 56 & 9 & 20 & 43 & 46 & 56 & 7 & 17 & 59 \\
\hline Maksat & 63 & 94 & 11 & 26 & 45 & 65 & 110 & 10 & 27 & 48 & 61 & 55 & 11 & 26 & 34 & 51 & 40 & 7 & 19 & 56 \\
\hline Vladlen & 61 & 81 & 9 & 22 & 52 & 58 & 88 & 9 & 23 & 56 & 56 & 56 & 8 & 22 & 35 & 44 & 40 & 7 & 16 & 57 \\
\hline Vatan & 62 & 85 & 10 & 24 & 45 & 67 & 101 & 10 & 30 & 48 & 58 & 54 & 9 & 22 & 41 & 50 & 39 & 6 & 15 & 50 \\
\hline Saana & 65 & 72 & 8 & 23 & 58 & 61 & 75 & 7 & 22 & 54 & 60 & 46 & 8 & 21 & 32 & 63 & 41 & 8 & 20 & 43 \\
\hline Marl & 67 & 86 & 11 & 26 & 56 & 65 & 111 & 10 & 27 & 63 & 55 & 61 & 10 & 28 & 38 & 61 & 51 & 9 & 26 & 41 \\
\hline Sencls & 65 & 93 & 11 & 27 & 52 & 64 & 108 & 11 & 27 & 56 & 58 & 67 & 10 & 26 & 40 & 54 & 55 & 8 & 21 & 58 \\
\hline Mette & 66 & 70 & 8 & 21 & 44 & 66 & 78 & 9 & 26 & 49 & 63 & 41 & 7 & 20 & 32 & 63 & 40 & 7 & 21 & 41 \\
\hline Pernilla & 65 & 89 & 10 & 24 & 54 & 61 & 95 & 10 & 27 & 54 & 58 & 63 & 10 & 24 & 45 & 58 & 52 & 8 & 23 & 52 \\
\hline KInnan & 67 & 85 & 8 & 26 & 41 & 72 & 78 & 8 & 22 & 42 & 62 & 42 & 8 & 21 & 26 & 67 & 32 & 7 & 14 & 48 \\
\hline Cecilla & 65 & 87 & 11 & 28 & 53 & 66 & 95 & 11 & 29 & 56 & 57 & 68 & 10 & 25 & 47 & 66 & 40 & 10 & 24 & 42 \\
\hline Leelo & 65 & 84 & 9 & 25 & 56 & 70 & 84 & 10 & 27 & 51 & 59 & 57 & 8 & 21 & 37 & 65 & 40 & 7 & 18 & 44 \\
\hline $\operatorname{Max}$ & 67 & 103 & 12 & 76 & 58 & 72 & 119 & 11 & 85 & 63 & 63 & 74 & 11 & 57 & 47 & 67 & 74 & 10 & 59 & 59 \\
\hline Min & 58 & 69 & 7 & 21 & 36 & 58 & 75 & 7 & 22 & 42 & 52 & 38 & 6 & 20 & 23 & 44 & 32 & 6 & 14 & 36 \\
\hline Avrage & 63 & 86 & 10 & 41 & 48 & 64 & 101 & 9 & 43 & 49 & 58 & 58 & 9 & 31 & 34 & 56 & 52 & 8 & 31 & 50 \\
\hline
\end{tabular}

from other cultivars having a shorter plant height $(32-42 \mathrm{~cm})$. Concerning the response of the six-rowed cultivars to environmental conditions there was a difference between the two years, but most cultivars were relatively consistent compared with plant heights in Kyrgyzstan. The barley cultivation in Kyrgyzstan often has unfavourable conditions and always with low input, like low soil nutrition content. Other poor agricultural practices could likewise influence plant height.

\section{Appendix 1}

The spike length values varied between the two years and locations, supposedly as a response to different environmental conditions. In Kyrgyzstan the spike length values ranged from 7 to $12 \mathrm{~cm}$ (average $10 \mathrm{~cm}$ ) in 2015, and from 7 to $11 \mathrm{~cm}$ (average $9 \mathrm{~cm}$ ) in 2016 (Fig. 2a). All two and six-rowed cultivars and landraces showed relatively stable SL values over the two years except for a few cultivars. In Latvia the spike length ranged between 6 and $11 \mathrm{~cm}$ (average $9 \mathrm{~cm}$ ) in 2015, and between 6 and $10 \mathrm{~cm}$ (average $8 \mathrm{~cm}$ ) in 2016 . Most advanced cultivars were stable in spike length comparison with landraces (Fig. 2b, Appendix 1). Two cultivars, i.e., 'Cecilia' from Sweden and 'Sencis' from Latvia, differed by having long spikes and constant behaviour $(11 \mathrm{~cm})$ during both years in Kyrgyzstan. However, four cultivars ('Cecilia' 'Pernila' 'Mari' and 'Saana') and one landrace ('Prostoy 1') were stable in spike length in each county for both years. There were no differences between countries (the P-value was greater than at 0.05 level; Table 4$)$. The number of grains per spike (NGS) is highly dependent on spike type. It is well-known that six-rowed barley has a clear advantage over two-rowed barley by having a higher number of grains per spike, but also the disadvantage that the grains are smaller in size and have lower weights [5152]. In this study, the NGS values of two-rowed cultivars were comparatively constant over the two years and in both countries, whereas six-rowed cultivars showed distinct responses to the environmental conditions. In Kyrgyzstan the number of grains per spikes of tworowed cultivars ranged from 21 to 28 (average 24) in 2015, and from 22 to 30 (average 25) in 2016 (Fig. 2a, Appendix 1). The NGS values of six-rowed cultivars ranged from 56 to 76 (average 68) in 2015 and from 47 to 85 (average 69) in 2016 (Fig. 2a, Appendix 1). In Latvia the number of grains per spike in two-rowed cultivars ranged from 20 to 28 (average 22) in 2015 and from 15 to 26 (average 20) in 2016 (Fig. 2b). In sixrowed cultivars the NGS values ranged from 33 to 57 (average 44) in 2015, and from 38 to 59 (average 48) in 2016 (Fig. 2b). Among the landraces (Obyknovenniy 2 , Prostoy 2) as well as six-rowed (Lavrance') and two rowed cultivars ('Nutans 89', 'Taalay', Odesskiy 100' ,'Kylym', 'Maksat', 'Vladlen', 'Saana', 'Mari', Pernilla' and 'Cecilia'), there were no significant differences at the 0.05 level when the compassion done between countries in NGS over both years.

Grain size was measured as thousand kernel weight (TKW), and it is commonly known that low TKW values lead to barley harvests [53-55]. The thousand kernel 
weight is genetically a very complex heritable trait and environmental factors always influence the development of grain size and weight [56-60]. The TKW values of cultivars ranged from 36 to $58 \mathrm{~g}$ (average $48 \mathrm{~g}$ ) in 2015, while in 2016 it ranged from 40 to $63 \mathrm{~g}$ (average $49 \mathrm{~g}$ ) in Kyrgyzstan (Fig. 2a). In Latvia the TKW values ranged from 23 to $47 \mathrm{~g}$ (average $34 \mathrm{~g}$ ) in 2015, whereas the range was from 36 to $59 \mathrm{~g}$ (average $50 \mathrm{~g}$ ) in 2016 (Fig. 2b, Appendix 1). In Latvia in 2016 the cultivars had a markedly higher TKW value compared to 2015 . In contrast, the TKW of seven cultivars and six sixrowed landraces in Kyrgyzstan were much more similar between the two years and without any obvious trends. However, in Latvia there were only two cultivars - 'Cecilia' and 'Mari' (Swedish), plus one landrace 'Obyknovenyi 1' (Russian) - that differed by having a consistent TKW in both years (Fig. 2a-b). The TKW of Kyrgyz cultivars was comparatively stable when the two countries were compared, and only three Swedish cultivars had a constant TKW.

\section{Conclusions}

Evaluation of breeding material through different eco-environmental conditions allows for a better understanding of the studied material in order to reveal new sources of useful adaptive traits for breeding programs. In our study the response to various environmental conditions was different depending on each agronomic trait. The TKW and NGS were comparatively stable in advanced cultivars than landraces. There are some superior cultivars, including 'Saana', 'Sencis','Cecilia', 'Mari' and 'Mette' from (Sweden and Latvia), which can be preferred as suitable material for the Kyrgyz barley breeding program for earliness, plant height, spike length and number of kernels, whereas among the six-rowed cultivars, 'Jyva', 'Lavrance' and 'Local 2' can be used for earliness, spike length, and NGS.

\section{Acknowledgements}

This project was supported by the Swedish International Development Agency (SIDA). The authors thank the staff at the Department of Plant Breeding, the Swedish University of Agricultural Sciences for all their support. We also thank Dr. Jan Eric Englund, Alnarp, for kind help with the statistical data treatments, and the Priekuli Plant Breeding Station in Latvia for providing the field experiments.

\section{Conflict of Interest}

The authors declare no conflict of interest.

\section{References}

1. ULLRICH SE Significance, adaptation, production, and trade of barley. Barley: Production, Improvement, and Uses, 3 (13), 2011.

2. MATHIAS WIEGMANNA, WILLIAM T.B. THOMASB, HAZEL J. BULLB, ANDREW J. FLAVELLC, ANNETTE ZEYNERD, EDGAR PEITERE, KLAUS PILLENA, ANDREAS MAURER "Wild barley serves as a source for biofortification of barley grains". Plant Science 283, 83, 2019

3. YAWSON D., MULHOLLAND B., BALL T., ADU, M., MOHAN S., WHITE P. Effect of climate and agricultural land use changes on UK feed barley production and food security to the 2050s. Land, 6 (4), 74, 2017.

4. USUBALIEV B. Barley genetic resources for kyrgyz plant breeding. Doctoral Thesis. Swedish University of Agricultural Sciences Alnarp, 2013.

5. DAWSON I.K., RUSSELL J., POWELL W., STEFFENSON B., THOMAS W.T.B., WAUGH R. Barley: a translational model for adaptation to climate change. New Phytol. 206, 913, 2015.

6. MARK O. WINFIELD, ALEXANDRA M. ALLEN, PAUL A. WILKINSON, AMANDA J. BURRIDGE, GARY L.A. BARKER, JANE COGHILL, CHRISTY WATERFALL, LUZIE U. WINGEN, SIMON GRIFFITHS, KEITH J. EDWARDS High-density genotyping of the AE Watkins collection of hexaploid landraces identifies a large molecular diversity compared to elite bread wheat. Plant Biotech. J. 16, 165, 2018.

7. INGVORDSEN C.H., GISLUM R., JØRGENSEN J.R., MIKKELSEN T.N.,. STOCKMARR A, JØRGENSEN R.B. Grain protein concentration and harvestable protein under future climate conditions. A study of 108 spring barley accessions. J. Exp. Bot. 67, 2151, 2016.

8. BARRETT R.D., SCHLUTER D. Adaptation from standing genetic variation. Trends in Ecology and Evolution, 23 (1), 38, 2008.

9. MERCER K.L., PERALES H. R. Evolutionary response of landraces to climate change in centers of crop diversity. Evolutionary Applications, 3 (5-6), 480, 2010.

10. RAGGI L., CECCARELLI S., NEGRI V. Evolution of a barley composite cross-derived population: an insight gained by molecular markers. Journal of Agricultural Science, 154 (1), 23, 2015.

11. MATSUMOTO T., TANAKA T., SAKAI H., AMANO N., KANAMORI H., KURITA K., KIKUTA A., KAMIYA K., YAMAMOTO M., IKAWA H., FUJII N., HORI K., ITOH T., SATO K. Comprehensive sequence analysis of 24,783 barley full-length cDNAs derived from 12 clone libraries. Plant Phys., 156, 20, 2011.

12. KUMAR V., KHIPPAL A., SINGH J., SELVAKUMAR R., MALIK R., KUMAR D., KHARUB A.S., VERMA R.P.S., SHARMA I. Barley research in India: Retrospect \& prospects. J.W.R., 6, 1-20, 2014.

13. LANGRIDGE P., WAUGH R. Harnessing the potential of germplasm collections. Nat. Genet. 51, 200, 2019.

14. RUSSELL J., MASCHER M., DAWSON I.K., KYRIAKIDIS S., CALIXTO C., FREUND F., BAYER M., MILNE I., MARSHALL-GRIFFITHS T., HEINEN S., HOFSTAD A., SHARMA R., HIMMELBACH A., KNAUFT M., VAN ZONNEVELD M., BROWN J.W., SCHMID K., KILIAN B., MUEHLBAUER G.J., STEIN N., WAUGH R. Exome sequencing of geographically diverse barley landraces and wild relatives gives insights 
into environmental adaptation. Nat. Genet. 48 (9), 1024, 2016.

15. SUNIL K.D. SEHRAWAT, MUJAHID KHAN Evaluation of Character Association in Barley (Hordeum vulgare L.) Genotypes for Yield and Yield Related Traits. Current Journal of Applied Science and Technology, 24 (1), 1, 2017.

16. DOCKTER C., HANSSON M. Improving barley culm robust-ness for secured crop yield in a changing climate. J Exp Bot 66, 3499, 2015.

17. POETS A.M., FANG Z., CLEGG M.T., MORRELL P.L. Barley landraces are characterized by geographically heterogeneous genomic origins. Genome Biol. 16 (173), 2015.

18. ARANTXA MONTEAGUDO, ANA M. CASAS, CARLOS P. CANTALAPIEDRA, BRUNO CONTRERAS-MOREIRA, MARÍA PILAR GRACIA AND ERNESTO IGARTUA Harnessing Novel Diversity From Landraces to Improve an Elite Barley Variety. Front Plant Sci. 10 (434), 2019.

19. PAULITZ T.C., STEFFENSON B.J. Biotic stress in barley: Disease problems and solutions. Barley production, improvement, and uses, 307-354, 2011.

20. KIELOCH R., WEBER R. Influence of Different Herbicides on the Performance of Spring Barley (Hordeum vulgare) Cultivars in Lower Silesia Region, Poland. Int. J. Agric. Biol., 17, 181-186, 2015.

21. FAOSTAT. Food and Agriculture Organization of the United Nations. Available online: http://www.fao.org/ faostat/en/ (accessed on 28 March 2019).

22. MYANMAR: National Action Plan for Agriculture (NAPA)Working Paper 13: Post-Harvest and Agroindustry, 2016.

23. AKAR T., KAPLAN M., YILMAZ S.H., SAGIR N., TABAK N., GELEBUR A., "Sustainable second-crop silage corn production under central anatolian highlands", Fresenius Environmental Bulletin, 25, 1078, 2016.

24. ARAUS J.L., SLAFER G.A., ROYO C., SERRET M.D. Breeding for yield potential and stress adaptation in cereals. Critical Reviews in Plant Science 27 (6), 377, 2008.

25. ARENAS-CORRALIZA M.G., ROLO V., LÓPEZ-DÍAZ M.L., MORENO G. Wheat and barley can increase grain yield in shade through acclimation of physiological and morphological traits in Mediterranean conditions. Sci Rep; 9 (1), 9547, 1-10, 2019.

26. MITTLER R., BLUMEALD E. Genetic engineering for modern agriculture: challenges and perspectives. Annu Rev Plant Biol., 61, 44, 2010.

27. BLAKE T., BLAKE V.C., BOWMAN J.G.P., ABDELHALEEM Barley Feed Uses and Quality Improvement. Barley: Production, Improvement, and Uses, 522, 2011.

28. National Statistical Committee of the Kyrgyz Republic, From, http://www.stat.kg/ru/statistics/selskoe-hozyajstvo, 2016.

29. BESSONOVA T.B. New cultivars of barley in Kyrgyz breeding. annual report of barley department of barley, Kyrgyz Resaerch institute of Farmig (annual report of barley department of barley, Kyrgyz Resaerch institute of Farmig), 2007.

30. FESS T.L., KOTCKON B.J., BENEDITO V.A. Crop breeding for low input agriculture: a sustainable response to feed a growing world population. Sustainability 3 (10), 1742, 2011.

31. DORÉ T., MAKOWSKI E.M., MUNIER-JOLAIN N., TCHAMITCHIAN M., TITTONELL P. Facing up to the paradigm of ecological intensification in agronomy: revisiting methods, concepts and knowledge. Eur. J. Agron. 34, 197, 2011.

32. GODFRAY H.C. et al. The challenge of food security. Science, 327 (80), 812, 2010.

33. PHAM T.D., GELETA M., BUI T.M., BUI T.C., MERKER A., CARLSSON A. Comparative analysis of genetic diversity of sesame (Sesamum indicum L.) from Vietnam and Cambodia using agro-morphological and molecular markers. Hereditas 148 (1), 28, 2011.

34. TILMAN D., CLARK M. Global diets link environmental sustainability and human health. Nature 515 (5), 18, 2014.

35. CRESPO-HERRERA L., ORTIZ R. Plant breeding for organic agriculture: something new? Agriculture \& Food Security 4 (25), 1, 2015.

36. MEŽAKA I., LOČMELE I., RUN̦GIS D., LEGZDIN,A L. Response of bi-parental spring barley populations to cultivation in organic and conventional farming systems. Zemdirbyste-Agriculture, 104 (2), 157, 2017.

37. FAO Statistics. Faostat Agricalture Retrived. From, http:// Fao.org/crop/statistics, 2016.

38. CECCARELLI S. Adaptation to low $\backslash$ high input cultivation. Euphytica 92, 203-214, 1996v

39. BLEIDERE M., MEŽAKA I., LEGZDIN̦A L., GRUNTE I., BEINAROVIČA I., ROSTOKS N. Variation of spring barley agronomic traits significant for adaption to climate change in latvian breeding programmes, 2012.

40. DOFING S., KNIGHT C., BERKE T., BAENZIGER P. Yield and yield component response of barley in subarctic and temperate environments. Canadian Journal of Plant Science 72 (3), 663, 1992.

41. KOLODINSKA-BRANTESTAM A. A century of breeding-is genetic erosion a reality? 30, 2005.

42. BOUZERZOUR H., REFOUFI B. Effect of sowing date and rate, and site environment on the performance of barley cultivars grown in the Algerian high plateaux. Rachis 11 (1/2), 19, 1992.

43. CECCARELLI S., GRANDO S., BAILEY E., AMRI A., EL-FELAH M., NASSIF F., REZGUI S., YAHYAOUI A. Farmer participation in barley breeding in Syria, Morocco and Tunisia. Euphytica 122 (3), 521, 2001.

44. BEZANT J., LAURIE D., PRATCHETT N., CHOJECKI J., KEARSEY M. Marker regression mapping of QTL controlling flowering time and plant height in a spring barley (Hordeum vulgare L.) cross. Heredity 77 (1), 64, 1996.

45. BAUM M., GRANDO S., BACKES G., JAHOOR A., SABBAGH A., CECCARELLI S. QTLs for agronomic traits in the Mediterranean environment identified in recombinant inbred lines of the cross' Arta' $\times \mathrm{H}$. spontaneum 41-1. TAG Theoretical and Applied Genetics 107 (7), 1215, 2003.

46. RAZAK A.A., ISMAIL M.R., KARIM M.F., WAHAB P.E.M., ABDULLAH S.N., KAUSAR H. Changes in leaf gas exchange, biochemical properties, growth and yield of chilli grown under soilless culture subjected to deficit fertigation. Aust J Crop Sci.7, 1582, 2013.

47. ZAIN N.A.M., ISMAIL M.R., MAHMOOD M., PUTEH A., IBRAHIM M.H. Alleviation of water stress effects on MR220 rice by application of periodical water stress and potassium fertilization. Molecules.19, 1795, 2014.

48. EL-KHOLY M., GABALLAH M., EL-ASHRY S., ORABY A. Combating drought using yield stabilizing agents in barley. J Agric Bio Sci 7 (3), 369, 2005.

49. KUCZYŃSKA A., SURMA M., ADAMSKI T., MIKOŁAJCZAK K., KRYSTKOWIAK K., OGRODOWICZ P. Effects of the semi-dwarfing sdwl/ 
denso gene in barley. Journal of Applied Genetics 54, 381, 2013.

50. AYOUB M., SYMONS S., EDNEY M., MATHER D. QTLs affecting kernel size and shape in a two-rowed by six-rowed barley cross. TAG Theoretical and Applied Genetics 105 (2), 237-247, 2002.

51. AMARE KEBEDE, MANJTT S.KANG, ENDASHAWBEKELE Chapter Five - Advances in mechanisms of drought tolerance in crops, with emphasis on barley. Advances in Agronomy, 156, 265, 2019.

52. INGVER A., TAMM I., TAMM Ü., KANGOR T., KOPPEL R. The characteristics of spring cereals in changing weather in Estonia. Agronomy Research 8, 553, 2010.

53. MATHIAS WIEGMANN, ANDREAS MAURER, ANH PHAM, TIMOTHY J. MARCH, AYED ALABDALLAT, WILLIAM T.B. THOMAS, HAZEL J. BULL, MOHAMMED SHAHID, JASON EGLINTON, MICHAEL BAUM, ANDREW J. FLAVELL, MARK TESTER, KLAUS PILLEN Barley yield formation under abiotic stress depends on the interplay between flowering time genes and environmental cues. Scientific Reports 9 (6397), 2019.

54. GRAFIUS J. A geometry for plant breeding. Crop science 4 (3), 241, 1964.

55. WENHUA WU, LEI ZHOU, JIAN CHEN, ZHENGJUN QIU, YONG HE GainTKW: A Measurement System of Thousand Kernel Weight Based on the Android Platform. Agronomy 8, 178, 2018.
56. LIU T., WU W., CHEN W., SUN C., CHEN C., WANG R., ZHU X., GUO W. A shadow-based method to calculate the percentage of filled rice grains. Biosyst. Eng. 150, 79, 2016.

57. FOX G.P., KELLY A., POULSEN D., INKERMAN A., HENRY R. Selecting for increased barley grain size. Journal of Cereal Science 43 (2), 198, 2006.

58. QIFEI WANG, GENLOU SUN, XIFENG REN, BINBIN DU, YUN CHENG, YIXIANG WANG, CHENGDAO LI, DONGFA SUN Dissecting the Genetic Basis of Grain Size and Weight in Barley (Hordeum vulgare L.) by QTL and Comparative Genetic Analyses. Frontiers in Plant Science, 10 (469), 2019.

59. ZHIMING FENG, CHUANYIN WU, CHUNMING WANG, JEEHEE ROH, LONG ZHANG, JUN CHEN, SHENGZHONG ZHANG, HUAN ZHANG, CHUNYAN YANG, JINLONG HU, XIAOMAN YOU, XI LIU, XIAOMING YANG, XIUPING GUO, XIN ZHANG, FUQING WU, WILLIAM TERZAGHI, SEONG-KI KIM, LING JIANG, JIANMIN WAN. SLG controls grain size and leaf angle by modulating brassinosteroid homeostasis in rice. Journal of Experimental Botany, 67 (14), 4241, 2016.

60. NADOLSKA-ORCZYK A., RAJCHEL I.K., ORCZYK W., GASPARIS S. Major genes determining yield-related traits in wheat and barley Theor Appl Genet 130, 1081, 2017.

61. ZHANG Y., LIU J., XIA X., HE Z. TaGS-D1, an ortholog of rice OsGS3, is associated with grain weight and grain length in common wheat. Mol Breed., 34, 1097, 2014. 